\title{
Groundwater Remediation and Protection at an Underground Leach Operation at Königstein, Germany
}

\author{
Jenk Ulf, Paul Michael \\ Wismut GmbH \\ Jagdschaenkenstrasse 19, Chemnitz,City, Germany \\ u.jenk@wismut.de; m.paul@wismut.de
}

\begin{abstract}
In 1963, the Königstein deposit was discovered in Upper Cretaceous sandstones of the Elbe rift valley southwest of Dresden (Germany). A total rock volume of some 9 million cubic metres including about 5 million cubic metres of ore was mined in a depth of 200 to $300 \mathrm{~m}$ using first by conventional mining, followed by an underground block leaching method as a response to decreasing ore grades. Leaching of the ore was performed with a sulphuric acid liquor. By 1990, more than 55 million tonnes of sandstone had come into contact with the leach liquor at the end of production in 1990, resulting in a dramatic change of hydrogeochemical conditions in the ore bearing sandstone aquifer. Uncontrolled flooding of the mine would have allowed the residual acid, uranium and other metals to rise from the deposit to the overlying aquifer an to the Elbe river. For this background the concept of controlled flooding as developed and successfully applied. The paper describes the remediation strategy, which allows a continuous washing out of soluble contaminates, but also the long term an high cost character of remediation of a leached aquifer.
\end{abstract}

Keywords: Uranium Minig, Leaching Operation, Aquifer Contamination, Aquifer Remediation.

\section{Introduction}

Systematic prospecting for Uranium in the upper Elbe river rift valley commenced in 1961 as part of large-scale uranium mining activities conducted in East Germany following the end of World War II. As a result, the Königstein deposit was discovered and opening-up work began in 1964 (Fig. 1).

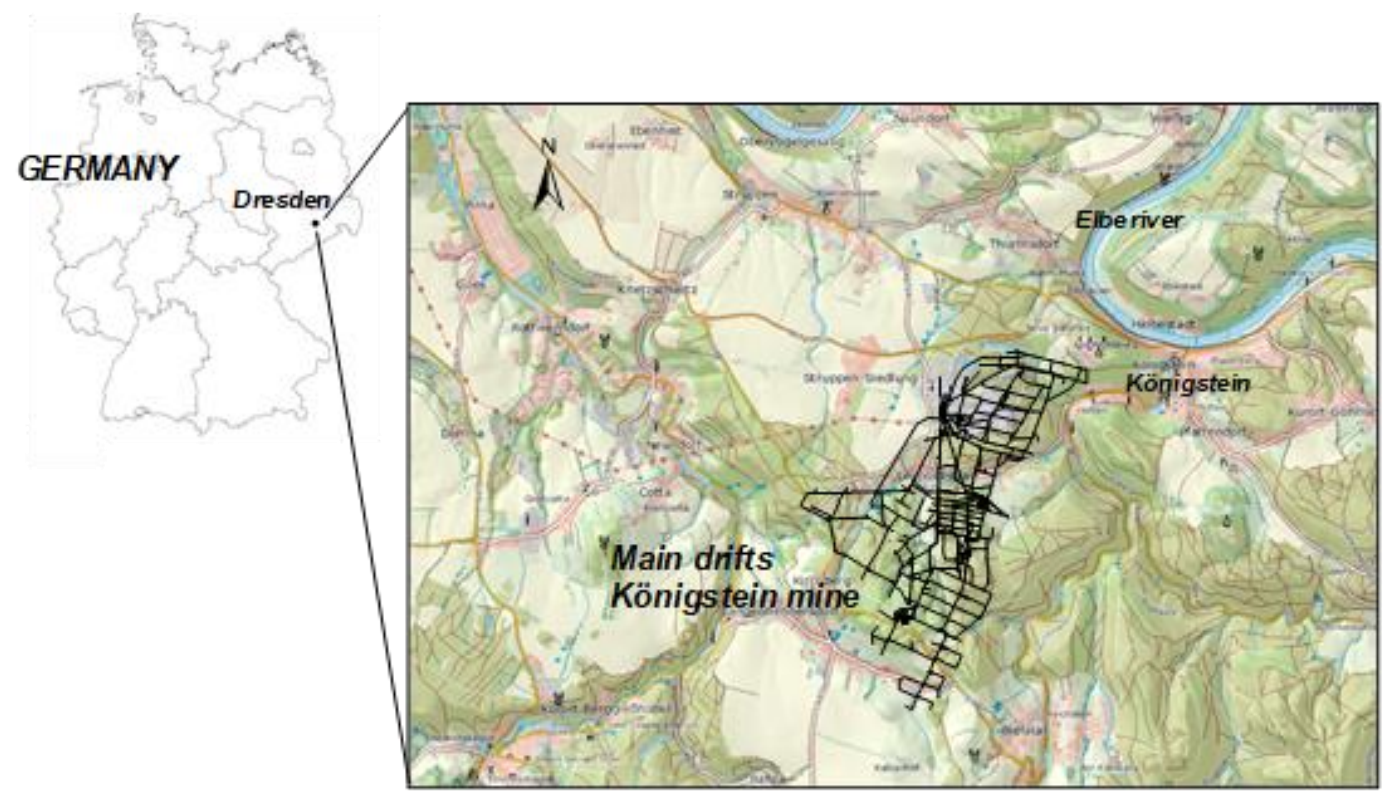

Fig. 1: Location, outline and floor levels of the Königstein Uranium mine. 
Mining operations using the room and pillar technique - initially with complete and later on with partial backfilling - commenced in 1967. The mine comprised 5 pit shafts and was developed on 4 levels within the lowermost of a system of four aquifers and extended over an area of approximately 6 square kilometres. Mined openings amount to ca. 8.7 million cubic metres of which ca. 4.5 million were backfilled. The depth of the deposit varied between $150 \mathrm{~m}$ in the South and $300 \mathrm{~m}$ in the North.

As early as the late 1960s, investigations were performed on in situ leaching as a response to relatively low ore grades and the good leachability of the uranium-bearing sandstones of the deposit. In 1984 the mine shifted to full underground leaching with sulphuric acid.

By the time uranium production was terminated on Dec. 31, 1990, the mine had produced ca. 18,000 tonnes of Uranium, of that total 5,750 tonnes by in situ leaching.

\section{Remediation Concept}

The Remedial concept for the rehabilitation of the Königstein mine had to address both the specific boundary conditions in terms of mining method (in situ leaching using sulphuric acid) and as the mine's location in a densely populated region within the Sächsische Schweiz Protected Landscape Area.

In compliance with the generally accepted cleanup goals for mines and contaminated sites and with a view to achieving a final condition as close to nature and as sustainable as possible, complete flooding of the mine was identified as the rehabilitation goal and applied for in the mine closure plan (1993) and approved by the Saxon Mining Office in 1994.

Implementation had to reconcile the ecologic and economic challenges of replenishing the aquifers depleted by mining operations and harnessing the leaching-induced potential of dissolved contaminants (uranium, radium, metals i.a.).

Flooding of the Königstein mine was preceded by 10 years of comprehensive preliminary studies and consideration of a number of remediation alternatives. The alternative eventually chosen called for monitored and controlled flooding involving operation of open control drifts (downstream horizontal wells) and treatment of the collected contaminated mine water in an above-ground facility.

As a response to regulatory reservations about the original application for a permit to flood (insufficient state of knowledge on system behaviour), in 1993 a multi-year flooding experiment was initiated in the deepest part of the mine (northern field) and extended in 1997. As a result of this large-scale experimental flooding, permits to proceed with the flooding of mine section \#1 up to a water level of 140 metres a.s.l. were issued in January 2001 under the Federal Mining

Act, under the Water Act and under the Radiation Protection Ordinance. The maximum allowable height of the flood water table (140 $\mathrm{m}$ a.s.1.) was established on the basis of predictions which excluded flood water discharges into the overlying third aquifer [1].

\section{Mine Flooding Section \# I - Results}

Flooding of mine section \#1 involved the saturation of all mined openings and backfills as well as of porous sandstones within the void subject to flooding. Inflow to the 3rd and 4th aquifer as well as imported water (intercepted groundwater) is used for flooding purposes.

The complete hydraulic shut-off of the flooded mine from the surrounding aquifers was made possible by the establishment of a system of control drifts located to the North, West and East and comprising drifts, bulkheads and a safety pillar bordering the void subject to flooding. A disturbed zone (North fault) with the potential of being of hydraulic relevance was monitored by a control drift established to the North at the level of the aquiclude separating the 3rd and 4th aquifer.

In an initial stage, the control drifts were operated in an open (non-flooded) mode. The mine water level was controlled by means of outlet devices at three bulkheads. Drainage water and flood water discharge were intercepted (separately from inflow of non-contaminated ground water) and pumped to the surface for treatment.

Surveillance during the operation of open control drifts was ensured by a comprehensive underground monitoring system for the atmospheric and water pathways and for geomechanical aspects.

For the flooding process to be continued the system of open control drifts had to be adjusted to operation in flooded condition. To this end, two pumping wells were drilled down to the Northern control drift. When control drifts were cut off 
from the rest of the mine in April 2010 the further rise of the flood water level and the discharge were controlled from then on by the system consisting of pumping wells plus flooded control drifts (Fig. 2).

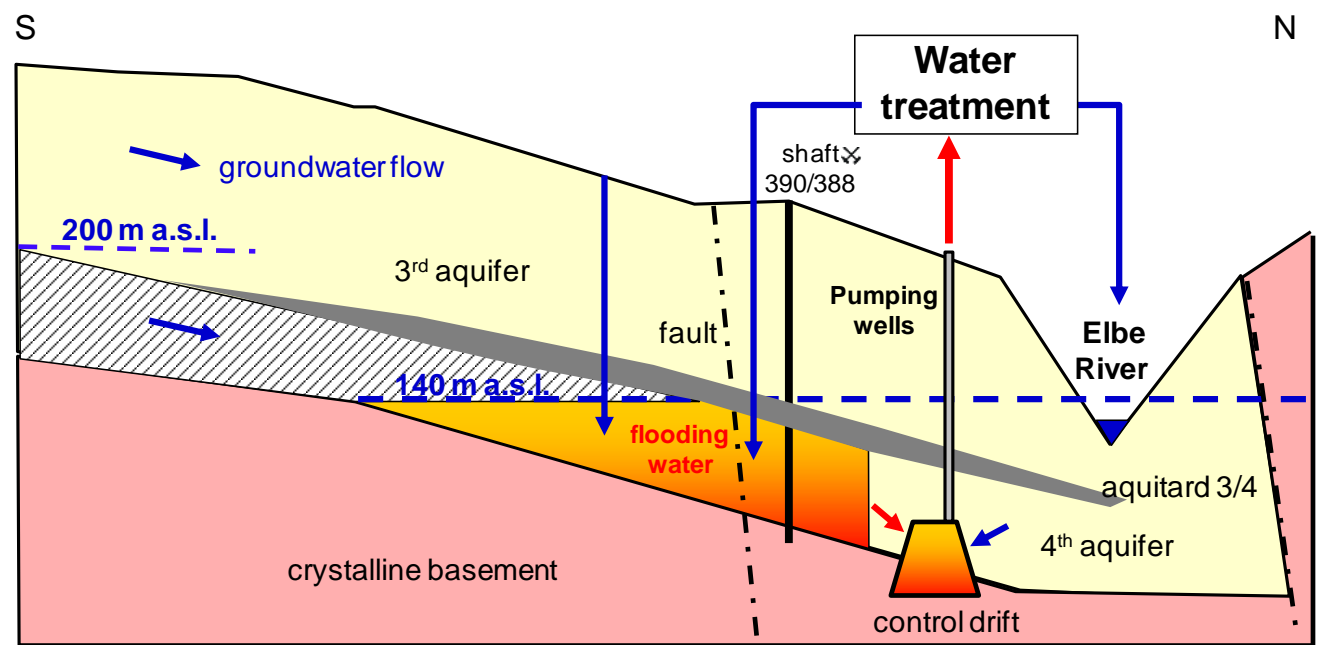

Fig. 2: Schematic representing flood water management by means of flooded control drifts and pumping wells.

Abandonment of the mine was completed in late 2012 when pit shafts 388/390 had been plugged and sealed [2].

The number of measurement points in the overall monitoring system has decreased from approximately 1,300 in 2001 to 690 in 2016; this was mainly due to the decommissioning of underground monitoring.

By early 2013 the flood water table had risen to a level of approximately 139 metres a.s.l. (governing factor). At that point a total water volume of some 7.4 million cubic metres had been impounded, ca. 2.4 million cubic metres inside the mine workings and ca. 5 million cubic metres within the pore volume of sandstones.

Based on findings provided by comprehensive investigations performed in the early 1990s, the residual contamination potential was estimated to be present in the mine in the form of highly polluted pore waters, residual liquor and easily soluble secondary minerals and be contained in the following quantities: ca. 2,400 tonnes of uranium, ca. 90,000 120,000 tonnes of sulphate, ca. 25,000 tonnes of iron, ca. 1,200 tonnes of zinc as well as smaller quantities of various other contaminants. Roughly one quarter of that potential was get out by removal of residual liquor in the 1990s.

At the beginning of flooding in 2001, flood water qualities varied heavily from location to location with rapidly increasing contaminant levels at low $\mathrm{pH}$. Peak contaminant levels were reached in 2002 (sulphate 3,800 mg/L, zinc $56 \mathrm{mg} / \mathrm{L}$, uranium approximately $260 \mathrm{mg} / \mathrm{L}$ ). As flooding continued, contaminant levels diminished. The concentration gradient followed a typical asymptotic wash-out curve with more contaminant potential being delivered from the pore space of the sandstones in the mine (Fig. 3). Flood water qualities during the flood process evolved to a great extent along the lines predicted in advance.

At the end of 2017 approximately 49 million cubic metres of water had been discharged as part of flooding mine section \#1 thereby removing a considerable amount of acid and dissolved contaminants from the void being flooded, namely ca. 1,060 tonnes of uranium and ca. 61,000 tonnes of sulphate, among others.

At a rough estimate, remediation measures of the 1990s and flooding so far has intercepted and disposed of in a nonhazardous way almost half of the mobile contaminant inventory. Regarding model based predictions further washing out of contaminatesdown to discharge limits needs decades. 


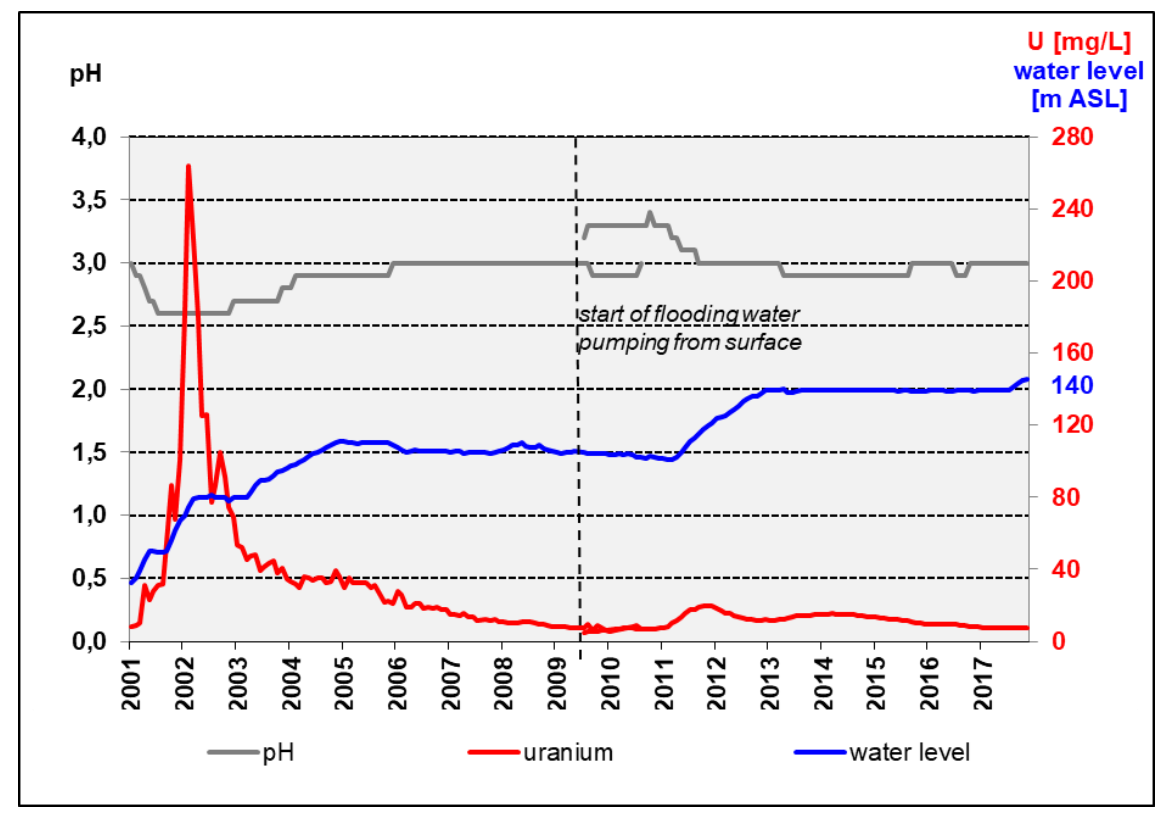

Fig. 3: Mine water level and hydrochemical development of the partliy flooded Königstein mine.

\section{Prospects}

With a flood water level kept at $<140$ metres a.s.l. it will be impossible to achieve the overriding public interest in achieving a sustainable rehabilitation, establishing natural ground water conditions, conducting remediation in a costeffective and efficient way and restoring pre-existing nature and habitat conditions.

While controlled complete flooding admittedly involves a hydraulically inevitable local contamination of the 3rd and 4th aquifer, the gradual and controlled rise of the flood water level in conjunction with contaminant fixation in the mine (injection of alkaline solutions) will considerably minimise such contamination. While this project allows a sustainable conclusion of site rehabilitation on the one hand, it diminishes to the extent possible environmental effects on the other, and exemplifies environmentally-friendly remedial work in compliance with the requirements of the Federal Mining Act.

Perpetual dewatering implies that remediation at the site remains incomplete with costs being incurred for an unforeseeable period of time. Moreover, one third of the mine and hence a radioactive contamination potential would be left non-remediated with the result that the mission to remediate would be left unaccomplished at this site.

As a consequence, a permit application has been filed in 2011 in order to continue mine flooding up to the natural, steady-state situation. The applications pursuant to the Mining Act and the Water Act were turned down. Since then Wismut $\mathrm{GmbH}$ is involved in an opposition proceeding concerning this matter against the Saxon Mining Office. Consultations at expert level have been going on for two years now in order to explore ways to have applications more clearly specified and to identify boundary conditions for approvability in principle. As a result, a hydraulic test for a temporary rise of the water level up to $150 \mathrm{~m}$ a.s.l. has been started in August 2017. By the end of 2017 water level reached $147 \mathrm{~m}$ a.s.l. without any interference of overlying 3rd aquifer.

\section{References}

[1] T. Metschies, U. Jenk, "Implementation of a modelling concept to predict hydraulic and geochemical conditions during flooding of a deep mine," The New Uranium Mining Boom, Challenges and Lessons learned, Springer Verlag Berlin Heidelberg, Germany, 2011.

[2] U. Jenk, M. Frenzel, T. Metschies, M. Paul, "Flooding of the underground uranium leach operation at Königstein (Germany) - A multidisciplinary report," in Proc. of Int. Mine Water Association Congress, Xuzhou, China, 2014. 